\title{
-RESEARCH PAPER-
}

\section{WORK-FAMILY SPILLOVER AND THE MEDIATING ROLE OF WORK ENGAGEMENT}

\author{
Safiye ŞAHIN \& Vedat AÇAR
}

\begin{abstract}
It is aimed to examine the effect of positive and negative family-to-work spillover on the positive and negative work-to-family spillover through work engagement in this study. The population of the study consisted of 490 healthcare employees working in a state hospital. The sample consisted of 228 employees who agreed to participate this study and filled out all questionnaires. Data were collected by questionnaire method. LISREL 8.80 and SPSS 22 software programs were used for analyzing the data. Results of the analyses revealed that positive family-to-work spillover had an effect on positive work -to-family spillover through work engagement. Negative family -towork spillover had no significant effect on negative work-to-family spillover through work engagement. This research was expected to contribute to the literature about work-family spillover.
\end{abstract}

Keywords: Positive Work-Family Spillover, Negative Work - Family Spillover, Work Engagement.

JEL Codes: M10, M12.

Başvuru: 14.06.2019 Kabul: 17.10.2019 


\section{İŞ-AİLE YAYILIMI VE ÇALIŞMAYA TUTKUNLUĞUN ARACI ROLÜ}

\section{$\ddot{O} z$}

Bu çalışmada pozitif ve negatif aile-iş yayılımının çalışmaya tutkunluk aracılı̆̆ ile pozitif ve negatif iş-aile yayılım üzerindeki etkisini belirlemek amaçlanmıştır. Araştırmanın evrenini bir devlet hastanesinde görev yapan 490 sağhk çalışanı oluşturmaktadır. Araştırmaya katılmayı kabul eden ve tüm anket sorularını eksiksiz cevaplayan 228 çalışan araştırmanın örneklemini oluşturmuştur. Veriler anket yöntemiyle elde edilmiştir. Verilerin analiz edilmesi için LISREL 8.80 ve SPSS 22 programları kullanılmıştır. Yapılan analizler sonucunda pozitif aile-iş yayılımının çalışmaya tutkunluk aracılı̆̆ı ile pozitif iş-aile yayılımı üzerinde etkisi olduğu belirlenmiştir. Negatif aile-iş yayılımının ise çalışmaya tutkunluk aracılı̆̆ı ile negatif iş-aile yayılımı üzerinde anlamlı etkisi olmadı̆̆ı tespit edilmiştir. Bu araştırmanın, iş-aile yayılımı hakkındaki literatüre katkı sağlaması beklenmektedir.

Anahtar kelimeler: Pozitif İş-Aile Yayılımı, Negatif İş-Aile Yayılımı, Çalışmaya Tutkunluk.

JEL Kodlart: M10, M12.

'Bu çalışma Araştırma ve Yayın Etiğine uygun olarak hazırlanmıştır.'

\section{INTRODUCTION}

Nowadays, there have been changes in the roles expected from women and men depending on work conditions. Increased participation of women in work life causes to an increase in the number of double-career families (Matias et al., 2017; Matysiak, Mencarini, \& Vignoli, 2016; Opie \& Henn, 2013). In addition to these changes, residing in the family life, changes in work life such as increasing competitive conditions, increased information-based jobs, and the importance given to employee motivation have also increased the importance of concepts such as work-life balance and work egagement. Work engagement is a prominent issue for organizations, because it leads to an increase in job performance. Although there are many variables that affect employee's job performance, studies have shown that the non-work life also affects the job performance.

Individuals have various roles both in their work life and non-work life (parent role, spouse role, child role, manager role, etc.) and these roles have some positive or negative effects on the individuals and their lives. There are two views explaining the effect of these roles (arising from work and family living spaces) on individuals (Rothbard, 2001). The first one is the view of depletion, which is related to resource depletion and role conflict, where roles negatively affect each 
other (Rothbard, 2001). Role conflict causes stress-based conflict in the individual as a result of the conflict in one role with the demands of another role (Greenhaus \& Beutell, 1985; Matias et al., 2017). A role in which stress rises makes it difficult to meet expectations in another role. Therefore, according to the opinion of depletion, demands in the work and family harm the individual and the individual's participation to the role, which cause stress and result in emotional stress (Bolino \& Turnley, 2005; Ernst, Kossek, \& Ozeki, 1998; Frone, Russell, \& Cooper, 1992; Matysiak, Mencarini, \& Vignoli, 2016). Studies on work - family conflict (WFC) generally accept this view. WFC is regarded as negative work - family spillover (Jin, Ford, \& Chen, 2013; Kinnunen, Geurts, \& Mauno, 2004; Roehling, Jarvis, \& Swope, 2005; Wayne, Lemmon, Hoobler, Cheung, \& Wilson, 2017). The second one is the view of enrichment, which suggests that one role will contribute to another role (Rothbard, 2001). According to the enrichment view, adhering to many roles provides various benefits to the individual rather than depleting the individual (Rothbard, 2001). This view supports positive spillover in work - family interaction (Andreassen, Hetland, \& Pallesen, 2013; Haar \& Bardoel, 2008; Kinnunen, Feldt, Geurts, \& Pulkkinen, 2006; Stevanovic \& Rupert, 2009; Stevens, Minnotte, Mannon, \& Kiger, 2007).

While there is a great number of studies examining negative work - family spillover, studies examining positive work - family spillover is limited (Stevens et al., 2007). In this research, negative work - family spillover and positive work - family spillover will be examined together. The work - family spillover that will be examined within the scope of this study is bidirectional (Geurts et al., 2003; Grzywacz, 2000; Grzywacz \& Marks, 2000). This study aims to test the effect of family -to- work spillover on work -to- family spillover. However, work -to- family spillover and family -towork spillover have been examined together as independent variables (Andreassen et al., 2013; Haar \& Bardoel, 2008; Ilies, Wilson, Wagner, \& Wagner, 2017; Wayne et al., 2017). This research will go over how positive or negative work experiences in family life affect work engagement in work life and how these experiences are transferred from work to family. Greenhaus and Powel (2006) have developed a theoretical model suggesting that positive experiences in one role will be transferred to another role. In the current study, Greenhaus and Powel's (2006, p. 79) theoretical model will be tested. To do this, work engagement is determined as a mediating variable in the relationship between the positive and negative family -to- work spillover and work -to- family spillover. There are other studies in the literature where work - family spillover and work engagement are examined together (Culbertson, Mills, \& Fullagar, 2012; Wayne et al., 2017). However, in our study, the effect of positive and negative family -to- work spillover on positive and negative work -to- family spillover via work engagement will be examined. Although there are theoretical studies on the effect of the family's negative or positive spillover on the work life, the emprical evidence is limited. In this respect, this research is expected to contribute to the literature and practical implication. 


\subsection{Literature Review}

\subsubsection{Work - Family Spillover}

Work - family spillover is explained by the spillover theory. According to the hypothesis of the spillover theory, emotions and attitudes in one living space are carried to another living space. For example, happiness in the workplace triggers happiness in the family (Zedeck \& Mosier, 1990). Studies on work and family interaction have shown that job satisfaction increases life satisfaction, negative emotions at work negatively affect emotions in other life areas in general. In addition, experience, talent and values gained at work are carried to the family living area (Zedeck \& Mosier, 1990). Clark (2000) defined spillover theory as a theory that adopts an open system approach (Clark, 2000). In this theory, although there are temporal and physical boundaries between work and family, emotions and behaviors are carried from one living space to another. For example, a person who has a stressful and bad day at work will also be in a bad state of mind when she/ he returns home.

Work - family spillover is divided into two groups as negative work - family spillover and positive work - family spillover (Geurts et al., 2003; Grzywacz, 2000). Negative work - family spillover is explained by role-stress theory. According to this theory, conflict arises for two reasons: overload and interference (Voydanoff, 2002). Overloading occurs when the sum of the time and energy demands in the roles is above the level to fulfill the role adequately. The intreference occurs in situations where it is difficult to meet the expectations of the role as a result of conflict in multiple roles. This occurs often when demands in multiple roles need to be met simultaneously. Negative work - family spillover is expressed as "a form of interrole conflict in which the role pressures from the work and family domains are mutually incompatible in some respect" (Greenhaus \& Beutell, 1985, p. 77). Negative work - family spillover is bidirectional, as work -to- family spillover and family -to- work spillover (Carlson, Kacmar, \& Williams, 2000; Frone, Russell, \& Cooper, 1992; Greenhaus \& Beutell, 1985; Netemeyer, Boles, \& Mcmurrian, 1996; Voydanoff, 2005).

Negative work -to- family spillover is the type of conflict or intervention from work to family that happens when the individual's roles in work life prevent him/ her from fulfilling his/her responsibilities in family life (Frone et al., 1992). This type of conflict is related to how much the expectations that should be fulfilled in work life prevent meeting family responsibilities. Negative family -to- work spillover is the type of conflict or intervention from family to work that happens because the family roles prevent the fulfillment of job-related duties (Voydanoff, 2005). This type of conflict is about how much the responsibilities to be fulfilled in family life prevent the meeting responsibilities in work life.

The concepts of work - family facilitation, work - family enrichment, and pos- 
itive work - family spillover can be used interchangeably (Greenhaus \& Powell, 2006; Wayne, Randel, \& Stevens, 2006). Positive work - family spillover refers that individuals are passionate about their duties in one living space, providing gains to support their fulfillment of their duties in the other living space (Wayne et al., 2006). According to Wayne, Grzywacz, Carlson, \& Kacmar, (2007), there are three important elements in the definition of positive work - family spillover named as engagement, enhanced functioning, and gains. Engagement is the level of dedication of the individuals to their duties in any living space (work or family). Gains are developmental gains (ability, knowledge, values, etc.), emotional gains (feeling safe, etc.), monetary gains, and effectiveness gains (attention in multiple roles, increasing experience, etc.) which are the resources that employees can obtain as a result of being passionate about their duties in a living space. The enhanced functioning is that these gains provide better fulfillment of duties in the other living space. Using problem solving skills, good communication, and improved performance are examples of enhanced functioning (Wayne, Grzywacz, Carlson, \& Kacmar, 2007). Rather than the conflict of work and family life, positive work - family spillover focuses on the positive synergy in the interaction of the two fields. Positive work - family spillover is bidirectional, such as negative work - family spillover, and their antecedents and outcomes are different (Grzywacz \& Butler, 2005). The positive work -to- family spillover is that the ability, behavior, and positive emotional state of working life positively affects family life. The positive family -towork spillover is that the emotional state, support, and sense of accomplishment of family life affects the working life, positively (Wayne, Musisca, \& Fleeson, 2004).

\subsubsection{Work Engagement}

Work engagment is defined as "a positive, fulfilling, work related state of mind that is characterized by vigor, dedication, and absorption" (Schaufeli, Salanova, González-romá, \& Bakker, 2002, p.74). Work engagement refers to a more persistent mental state that does not consist of a special or momentary situation, and does not concentrate a special purpose, event, person and behavior. Vigor, which is one of the sub-dimensions of work engagement, is expressed as "high levels of energy and mental resilience while working, the willingness to invest effort in one's work, and persistence even in the face of difficulties". In other words, the individuals are willing to give their energy to their jobs and be resistant even when they encounter difficulties at work. Dedication is expressed as "a sense of significance, enthusiasm, inspiration, pride, and challenge” (Schaufeli et al., 2002, p.74). Absorption, is defined as "being fully concentrated and deeply engrossed in one's work, whereby time passes quickly and one has difficulties with detaching oneself from work" (Schaufeli et al., 2002, p.75).

\subsubsection{Work - Family Spillover and Work Engagement}

Individuals have multiple roles both in work and family lives and can be engaged 
to these roles. For instance, family life of an employee who has to make business trips will be affected. For an executive who wants employees to be engaged to their roles in the workplace, the impact of being engaged to family roles on work roles is an important question. Likewise, the impact of being engaged to job roles on the family is an equally important question for an employee who will make a career choice. According to Rothbard (2001), in both views- depleting and enrichmentthe emotional responses of individuals regarding their roles are important and determining which of these emotional responses will occur. While negative emotions are associated with depleting view, positive ones are associated with enrichment view. Rothbard (2001) found that the view of depletion is common only for women from work to the family direction, while the view of enrichment is common for men from work to the family direction and common for women from family to the work direction.

Turgut (2011), on the other hand, suggested that work - family conflict will have a negative effect on work engagement. According to the findings of the research carried out by Turgut (2011), it was determined that work - family conflict had negative effects on vitality and dedication, which are two sub-dimensions of work engagement. Likewise, Burke, Koyuncu, Fiksenbaum, and Tekin (2013), in their research on a sample of 549 employees in 15 hotels in Alanya (four and five stars), showed that the family -to- work conflict and the work -to- family conflict have a significant relationship with work engagement. Richman et al. (2008) found that organizational policies that support perceived flexibility and work-life balance are positively related with work engagement (Richman, Civian, Shannon, Jeffrey Hill, \& Brennan, 2008).

Within the scope of this study, we aim to test the relationships between work - family spillover and work engagement based on the model developed by Greenhause and Powel (2006). Greenhause and Powel (2006) explained how the experiences in one living space or role affected the life quality in the other living space or role (Figure 1). 
Figure 1: Model of Work - Family Enrichment

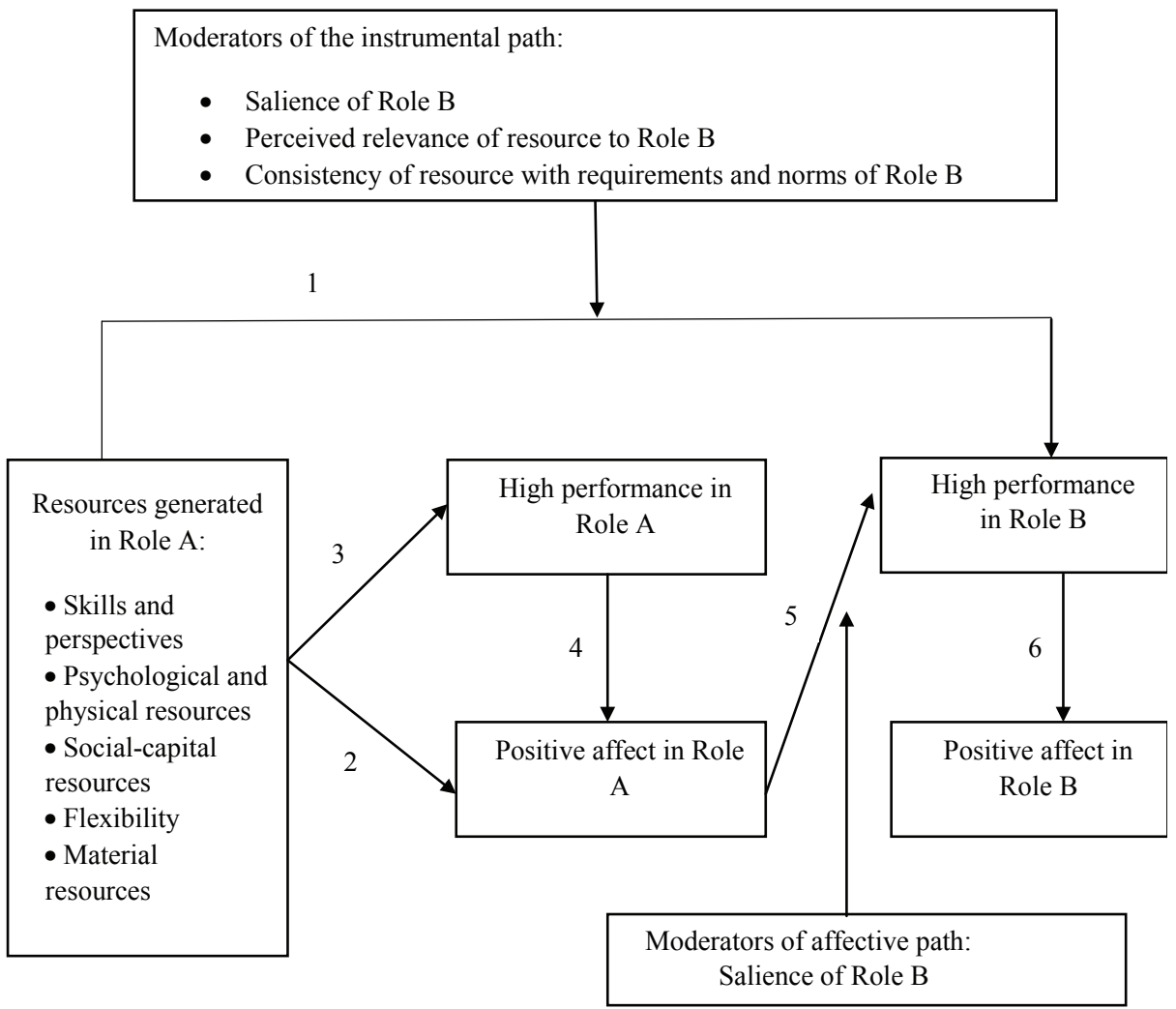

Source: Greenhaus, J. H., \& Powell, G. N. (2006). When Work and Family Are Allies: A Theory of Work - Family Enrichment. Academy of Management Review, 31(1), p. 79.

This model (Figure 1) shows that the resources (experience, skill, social support, money, gifts, etc.) obtained from a role will have a positive effect on both the role itself and the other role. In addition, high performance in one role will be transferred to the other role, leading positive emotions. Therefore, as a result of family life affecting work life positively, the level of employees' work engagement will increase. In addition, work engagement is explained in line with the Job Demands-Resources Model (Demerouti, Bakker, Nachreiner, \& Schaufeli, 2001). Job resources are physical, psychological, social, and organizational resources that will make it easier to meet job demands. In the presence of these resources, the level of work engagement is expected to increase (Demerouiti, Bakker, Nachreiner, \& Schaufeli, 2001). The positive and negative family -to- work spillovers are determined as the antecedents of work engagement, and the positive and negative work -to- family spillovers are determined as the outcomes of work engagement in our study. Greenhause and Powel (2006) examined only positive work - family spillover in the model they developed. We examined positive and negative work 
- family spillover together. In this direction, the hypotheses of the research are as follows:

H1: Positive family -to- work spillover has an impact on positive work -to- family spillover through work engagement.

H2: Negative family -to- work spillover has an impact on negative work -to- family spillover through work engagement.

\section{METHOD}

\subsection{Research's Aim and Model}

The aim of this research is to test the impact of positive and negative family -towork spillovers on positive and negative work -to- family spillovers via work engagement. The research model is shown in Figure 2:

Figure 2: Research's Model

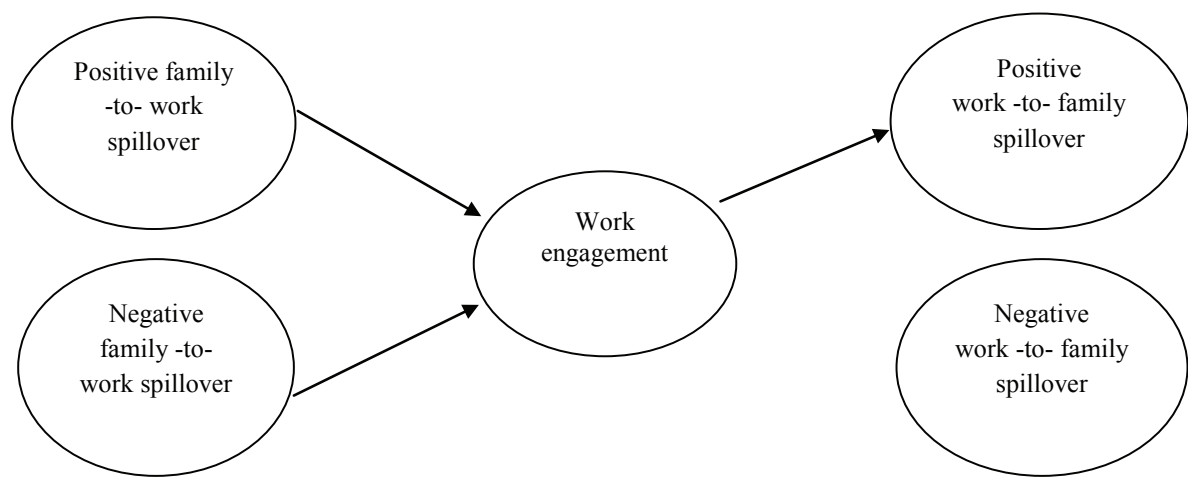

\subsection{Sample}

The universe of this study consisted of 490 healthcare professionals working in a state hospital. The data of 228 employees who accepted to participate in the research and answered all the questionnaires completely constituted the sample of the study. 
Table 1: Distribution of Employees' Demographic Features

\begin{tabular}{llrr} 
& & n & \% \\
\hline \multirow{3}{*}{ Age } & 22 to 29 & 79 & 34.6 \\
(year) & 30 to 37 & 44 & 19.3 \\
& 38 to 45 & 68 & 29.8 \\
Gender & Higher than 46 & 37 & 16.2 \\
\multirow{3}{*}{ Marital status } & Female & 128 & 56.1 \\
& Male & 100 & 43.9 \\
\multirow{3}{*}{ Education } & Married & 143 & 62.7 \\
& Single & 85 & 37.3 \\
& High School & 56 & 24.6 \\
& Vocational School & 68 & 29.8 \\
& Bachealor's Degree & 85 & 37.3 \\
& Master's Degree & 19 & 8.3 \\
\hline
\end{tabular}

The socio-demographic characteristics of the participants are presented in Table 1. $56,1 \%$ of the respondents were female and $62,7 \%$ were married. While $34,6 \%$ of the respondents were in the 22-29 years of age group, 16,2\% were age of 46 years and above. In addition, while 24,6\% graduated from high school, 29,8\% graduated vocational school, $37,3 \%$ held bachealor's degree, and 8,3\% held master's degree. The distribution of professional characteristics of the respondents are shown in Table 2 .

Table 2: Distribution of Professional Characteristics of Employees

\begin{tabular}{llrr} 
& & n & \% \\
\hline \multirow{2}{*}{ Managerial Position } & Manager & 25 & 11.0 \\
Working Areas & Non-manager & 203 & 89.0 \\
\cline { 2 - 4 } & Health services & 142 & 62.3 \\
& Administrative services & 86 & 37.7 \\
\cline { 2 - 4 } & $\leq 1$ & 19 & 8.3 \\
Organizational Tenure & 1 to 5 & 89 & 39.0 \\
(year) & 6 to 10 & 52 & 22.8 \\
& 11 to 15 & 32 & 14.0 \\
& 16 to 20 & 9 & 3.9 \\
Occupational Tenure & Higher than 21 & 27 & 11.8 \\
\cline { 2 - 4 } (year) & $\leq 5$ & 66 & 28.9 \\
& 6 to 11 years & 48 & 21.1 \\
& 12 to 17 years & 45 & 19.7 \\
\hline
\end{tabular}

Distribution of the employees as professional characteristics was examined as well; $11 \%$ of the participants were manager, while $89 \%$ were a non-manager staff. $62,3 \%$ of the participants worked in health services, $37,7 \%$ worked in administrative services. It was determined that majority of the participants had the organizational tenure between 1-5 years (39\%) and $28,9 \%$ had a $0-5$ years of occupational tenure. 


\subsection{Measures}

The data were collected using a questionnaire method. All scales were 5-point Likert type scales ( 1 = Never, 5 = Always). We used to work - family spillover scale developed by Grzywacz and Marks (2000). The scale was adapted into Turkish by Polatçı (2014). In the study of Polatçı (2014), the internal consistency of the scale is above 0.70 for all sub-dimensions. This scale has 14 items and four subdimensions. Sample items of the scale are as follows:-

1. "Stress at work makes you irritable at home." (Negative Work-to-family spillover-NIAY)

2. "Personal or family worries and problems distract you when you are at work." (Negative Family -to- work spillover-AINY)

3. "The love and respect you get at home makes you feel confident about yourself at work." (Positive Family -to- work spillover-PAIY)

4. "The things you do at work help you deal with personal and practical issues at home." (Positive Work-to-family spillover-IAPY)

In order to measure the work engagement, Ultra-Short Form of Utrecht Work Engagement Scale (UWES-3) was used. Schaufeli et al. (2017) tested the validity of this scale in five countries and reported that the a coefficients were over 0.70 for all five countries (Schaufeli, Shimazu, Hakanen, Salanova, \& De Witte, 2017). Şahin and Çankır (2018) reported that the scale was reliable $(\alpha=0.88)$ in Turkish sample. There is no reverse expression on the scale consisting of one dimension. The items on the scale are as follows:

"At my work, I feel bursting with energy"

"I am enthusiastic about my job"

"I am immersed in my work"

\subsection{Data Analysis}

LISREL 8.80 and SPSS 22 software programs were employed to analyze the data. Firstly, the skewness and kurtosis values of the descriptive data were examined to determine the suitability of the data to the normal distribution. According to Kline (2011), the skewness value should not exceed \pm 3 and the kurtosis value should not exceed \pm 10 as an indicator of the suitability of the data for normal distribution. Accordingly, it has been determined that the data were suitable for normal distribution. LISREL 8.80 program was employed to test the validity of the scales and the research's model.

There are several methods for determining whether there is multicollinearity in testing the research model (Adeboye, Fagoyinbo, \& Olatayo, 2014; Giacalone, Panarello, \& Mattera, 2018; Mansfield et al., 2018; Yoo et al., 2014). First, if the 
correlation coefficient between the independent variables is 0.70 , and 0.85 and above for some sources, multicollinearity problems occur. The second indicator is that Variance Inflation Values (VIF) are 10 and above. In addition, the ratio of eigenvalues to largest to smallest $(\lambda \max / \lambda \min )$ is used as an indicator of multicollinearity. If the ratio of eigenvalues $(\lambda \max / \lambda \min )$ is between $100-1000$, it is mentioned that there is a medium multicollinearity. If it is greater than 1000, then there is strong multicollinearity. Finally, the condition index greater than 30 indicates that there is a multicollinearity problem. In accordance with these criteria, the research data were analyzed to check whether there was a multicollinearity problem and it was not found:

1. Correlations between independent variables were examined. Correlation between the independent variables were found to be less than 0.70 .

2. VIF (Variance magnification factor) value was less than 10 for all variables.

3. The ratio of the eigenvalues (the largest to smallest) $=206$.

4. The condition index was less than 30 .

\section{RESULTS}

\subsection{Results Related to the Validity-Reliability Analysis of the Scales}

Validity analyzes of the scales were tested with Exploratory and Confirmatory Factor Analysis. While Exploratory Factor Analysis (EFA) is used as a discoverer in scale development studies, Confirmatory Factor Analysis (CFA) is used to re-analyze the validity of the scales existing in the literature with the data of the researcher (Hair et al., 2010). Since the scales used within the scope of this research are theoretically defined and previously validated, the validity was tested with CFA. The CFA results were shown in Figure 3. Observed variables (NIA1, AIN1, PAI3 and IAP2), which caused a decrease in the chi-square value, were removed from the measurement model in line with the suggestions of modification indices. 


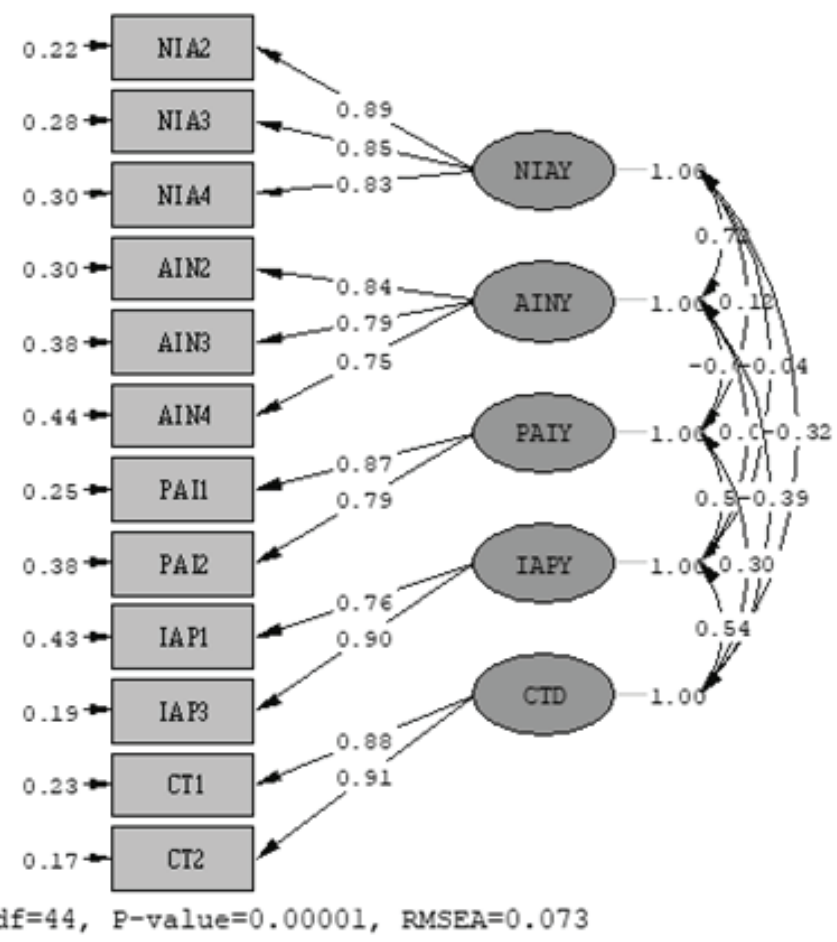

\section{Figure 3: Results of CFA}

The fit indices for the measurement model of the CFA are shown in Table 3.

Table 3: Fit Indices of the Measurement Model

\begin{tabular}{lccc}
\hline Fit Indices & Measurement Model & Good Fit & Acceptable Fit \\
\hline $\mathrm{X}^{2} / \mathrm{sd}$ & 2.22 & $0-2$ & $2-5$ \\
\hline RMSEA & 0.07 & $0-0.05$ & $0.05-0.08$ \\
\hline NFI & 0.95 & $0.95-1$ & $0.90-0.95$ \\
\hline NNFI & 0.95 & $0.97-1$ & $0.95-0.97$ \\
\hline CFI & 0.97 & $0.97-1$ & $0.95-.97$ \\
\hline GFI & 0.93 & $0.95-1$ & $0.90-0.95$ \\
\hline AGFI & 0.88 & $0.90-1$ & $0.85-0.90$ \\
\hline
\end{tabular}

Source: (Byrne, 2001; Hair et al., 2010; Hooper, Coughlan, \& Mullen, 2008; Jöreskog, 1993) According to Table 3, while RMSEA, AGFI and GFI were in the acceptable fit range, other fit indices were in good fit range. 
Table 4: CR and AVE Coefficients for the Final Measurement Model

\begin{tabular}{|c|c|c|c|c|c|}
\hline & $\begin{array}{l}\text { Standard } \\
\text { Loadings }\end{array}$ & Error & $\begin{array}{l}\text { Composite } \\
\text { Reliability } \\
\text { (CR) }\end{array}$ & $\begin{array}{l}\text { Square of } \\
\text { Standard } \\
\text { Loadings }\end{array}$ & $\begin{array}{c}\text { Average } \\
\text { Variance } \\
\text { Extracted (AVE) }\end{array}$ \\
\hline \multirow{3}{*}{$\begin{array}{l}\text { Negative Work -from- } \\
\text { family spillover }\end{array}$} & 0.89 & 0.22 & 0.892 & 0.7921 & 0.73 \\
\hline & 0.85 & 0.28 & & 0.7225 & \\
\hline & 0.83 & 0.3 & & 0.6889 & \\
\hline \multirow{3}{*}{$\begin{array}{l}\text { Negative Family -from- } \\
\text { work spillover }\end{array}$} & 0.84 & 0.3 & 0.829 & 0.7056 & 0.62 \\
\hline & 0.74 & 0.38 & & 0.5476 & \\
\hline & 0.75 & 0.44 & & 0.5625 & \\
\hline \multirow{2}{*}{$\begin{array}{l}\text { Positive Work -from- } \\
\text { family spillover }\end{array}$} & 0.87 & 0.25 & 0.814 & 0.7569 & 0.69 \\
\hline & 0.79 & 0.38 & & 0.6241 & \\
\hline \multirow{2}{*}{$\begin{array}{l}\text { Positive Work -from- } \\
\text { family spillover }\end{array}$} & 0.76 & 0.43 & 0.816 & 0.5776 & 0.69 \\
\hline & 0.9 & 0.19 & & 0.81 & \\
\hline \multirow{2}{*}{ Work Engagement } & 0.88 & 0.23 & 0.889 & 0.7744 & 0.80 \\
\hline & 0.91 & 0.17 & & 0.8281 & \\
\hline
\end{tabular}

Convergence and discriminant validity of the research scales were also tested. To ensure convergence validity, the composite reliability (CR) of all implicit variables should be above 0.60 and above 0.50 for the Average Variance Extracted (AVE) values of all implicit variables (Hair et al., 2010; Voorhees, Brady, Calantone, \& Ramirez, 2016). Table 4 shows the standardized factor loadings, CR, and AVE coefficients of the measurement model. When we examine Table 4, it is clear that the AVE coefficients of the scales are above 0.50 and CR values are above 0.60. Therefore, these results are important indicators that the scales provide convergence validity.

Correlations between implicit variables should take a value below 0.85 to ensure the discriminant validity of the scales (Kline, 2011). Table 5, presents that correlation coefficients between the variables are below 0.85 . Based on this, it can be explained that the scales had discriminant validity.

\subsection{Results of Descriptive Statistics and Relationship Among Vari- ables}

Table 5 shows the mean scores and the Cronbach's Alpha coefficients of the variables. The mean scores of the positive work - family spillover were higher than the negative work - family spillover. The mean score of the positive family -to- work spillover was $3.96 \pm 1.06$, while the mean score of the negative work -tofamily spillover was $3.10 \pm 1.22$. The lowest mean score was $2.50 \pm 1.16$, belonging to the negative family -to- work spillover. These results showed that the participants perceive that the work life negatively affects family life rather than the family life negatively affects work life. The mean score of work engagement was 3.66 \pm 1.08 . 
The correlations between negative work -to- family spillover \& negative family -to- work spillover $(\mathrm{r}=0.582, \mathrm{p}<0.01)$ and positive work -to- family spillover $\&$ positive family -to- work spillover $(\mathrm{r}=0.392, \mathrm{p}<0.01)$ were found significant. The correlation of the mediating variable with all other study variables were also significant $(p<0.01)$. In addition, the reliability coefficients of the variables $(\alpha)$ were above 0.70 .

Table 5: Descriptive Statistics, Reliability Coefficients, and Correlation Coefficients of Variables

\begin{tabular}{lccccccc}
\hline Variables & Mean & S.D. & 1-NIAY & 2-AINY & 3-PAIY & 4-IAPY & 5-CTD \\
\hline 1-NIAY & 3.10 & 1.22 & $(0.839)$ & & & & \\
\hline 2-AINY & 2.50 & 1.16 & $.582^{* *}$ & $(0.781)$ & & & \\
\hline 3-PAIY & 3.96 & 1.06 & 0.092 & 0.003 & $(0.723)$ & & \\
\hline 4-IAPY & 3.54 & 1.07 & -0.027 & 0.064 & $.392^{* *}$ & $(0.754)$ & \\
\hline 5-CTD & 3.66 & 1.08 & $-.262^{* *}$ & $-.274^{* *}$ & $.205^{* *}$ & $.366^{* *}$ & $(0.848)$ \\
\hline
\end{tabular}

${ }^{* *} p<0,01$ NIAY: Negative Work -from-family spillover, AINY: Negative Family-from-work spillover, PAIY: Positive Family-from-work spillover, IAPY: Positive Work-from-family spillover, CTD: Work Engagagement

\subsection{Results of The Test Model}

Fit indices of the test model are presented in Table 6. According to Table 6, the model showed acceptable fit with the data.

\begin{tabular}{llll}
\hline \multicolumn{4}{l}{ Table 6: Fit Indices of the Structural Model } \\
\hline Fit Indices & Test Model & Good Fit & Acceptable Fit \\
\hline $\mathrm{X}^{2} / \mathrm{sd}$ & 2.653 & $0-2$ & $2-5$ \\
\hline RMSEA & 0.085 & $0-0.05$ & $0.05-0.08$ \\
\hline NFI & 0.94 & $0.95-1$ & $0.90-0.95$ \\
\hline NNFI & 0.94 & $0.97-1$ & $0.95-0.97$ \\
\hline CFI & 0.96 & $0.97-1$ & $0.95-0.97$ \\
\hline GFI & 0.92 & $0.95-1$ & $0.90-0.95$ \\
\hline AGFI & 0.86 & $0.90-1$ & $0.85-0.90$ \\
\hline
\end{tabular}

The T-values of the test model, which shows the effect of positive and negative family -to- work spillover on the positive and negative work -to- family spillover through work engagement, are presented in Figure 4 and standardized values of the test model are shown in Figure 5.

The effect of the work engagement on negative work -to- family spillover was not significant while the other path coefficients were significant (Figure 4). In the mediation model, the effect of the mediating variable on the dependent variable should be significant. Therefore, the second hypothesis $(\mathrm{H} 2)$ of the study was not supported. 
Figure 4: T-Values of the Test Model

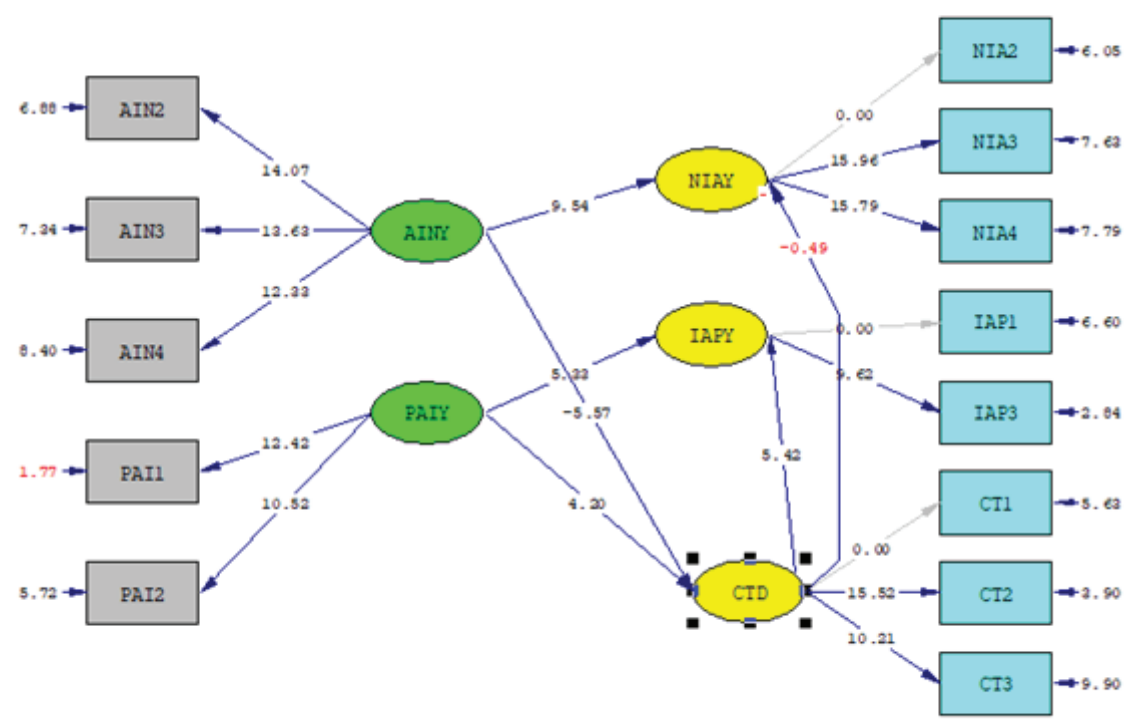

Chi-8quare=165. 07, df=58, p-qalue=0.00000, Rusgam=0.091

Figure 5: Standardized Values for the Test Model

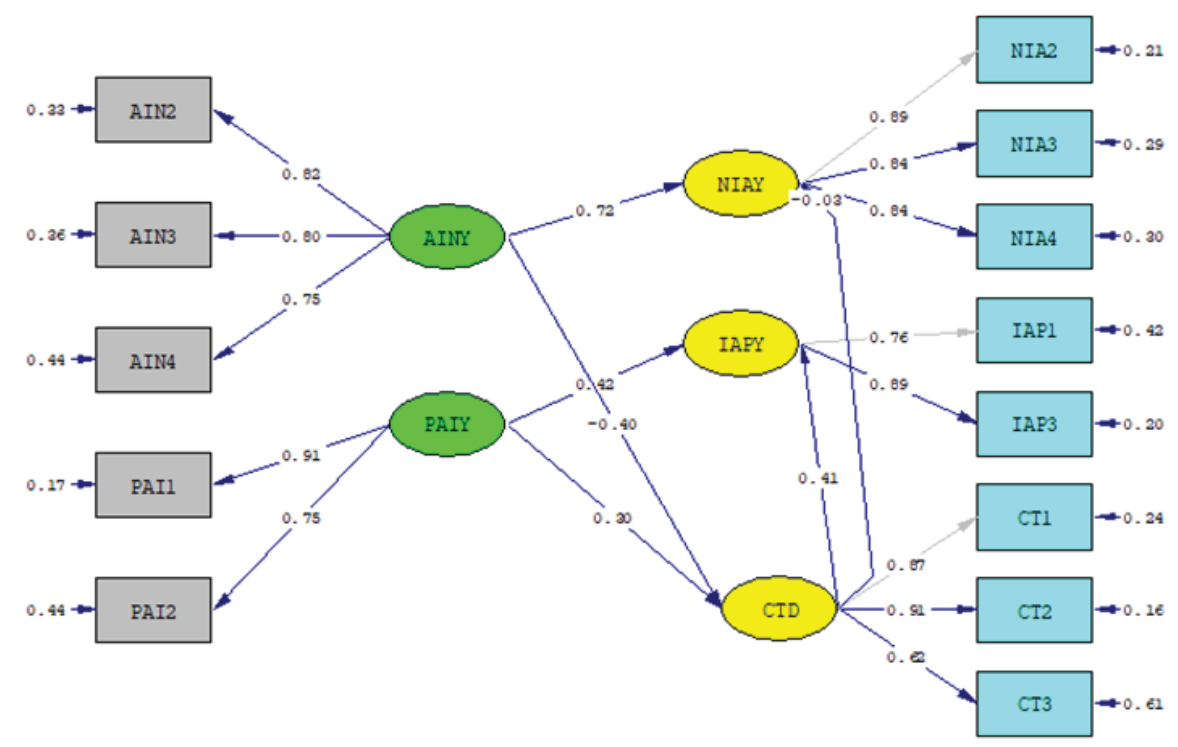

Chi-9quare $=165.87, d f=58, p-v a 1$ ue $=0.00000$, RMgEA $=0.091$

Structural balances for the test model were as follows:

Positive Work -to- Family Spillover $=0.42 *$ Work Engagement $+0.42 *$ Positive 
Family -to- Work Spillover, $\mathrm{R}^{2}=0.44$

Positive Work -to- family spillover $=0.61^{\star}$ Positive Family -to- work spillover, $\mathrm{R}^{2}=0.37$

As a result of testing the research model, it was determined that the $\mathrm{H} 1$ hypothesis was supported. The positive family -to- work spillover itself describes $37 \%$ of the positive work -to- family spillover, and the standardized beta coefficient was 0.61. The positive family -to- work spillover explains $44 \%$ of the positive work -tofamily spillover through work engagement, and the standardized beta coefficient drops from 0.61 to 0.42 . These findings showed that work engagement has a partial mediating role in the effect of positive family -to- work spillover on positive work -to- family spillover.

\section{DISCUSSION}

This study was carried out to determine the effect of positive and negative family -to- work spillover on positive and negative work -to- family spillover through work engagement. The research model was tested on the sample of healthcare professionals. Research findings demonstrated that work engagement had a mediating role in the relationship between positive family -to- work spillover and positive work -to- family spillover. Positive work - family spillover has been examined as results of work engagement (Culbertson, Mills, \& Fullagar, 2012; Siu et al., 2010). Siu et al. (2010) reported that work engagement positively affected the positive family -to- work spillover and positive work -to- family spillover. Culbertson, Mills, \& Fullagar, (2012) reported that work engagement positively affected the positive family -to- work spillover. These findings were in line with the results of our study.

Significant and inverse relationship between the negative work - family spillover \& work engagement was found as well. This finding was consistent with the results of the study conducted by Wayne et al. (2017). In addition, Turgut (2011, p. 159) found that work - family conflict has a negative impact on work engagement. Likewise, Burke et al. (2013, p. 200) found that family intervention between work and family had a negative relationship with work engagement. In addition, although there was a significant and inverse relationship between negative work - family spillover and work engagement in this study, the effect of negative family -to- work spillover on negative work -to- family spillover through work engagement was found to be insignificant. This finding was likely to occur as a result of work engagement closely related to positive emotions. Although work engagement is theoretically a positive antithesis of burnout, its structure differs from burnout; they are negatively related with each other, but this relationship is not perfect (Schaufeli et al., 2002, p. 75). Burnout and work engagement have also been proved by independent variables (Schaufeli et al., 2002, p. 75, Schaufeli \& Bakker, 2004, p. 295). 


\section{CONCLUSION}

There are many studies on the effects of negative work - family spillover on individuals and organizations. However, positive work - family spillover and the effects of work and family living spaces on each other have not been emphasized, so far. In this study, it was aimed to contribute to the existing work - family literature by examining the effect of positive family -to- work spillover on positive work -tofamily spillover through work engagement. The theoretical contribution of this study is that it fills the gap in the literature on positive work - family spillover and enables the development of new research models especially on the effect of work - family living spaces on each other. The hypotheses of this research are based on the theoretical model developed by Greenhaus and Powell (2006). From this point of view, this model has been tested with the data of this research. The results of the current research can support this theoretical model.

Our study provides important findings for the application area and managers regarding the importance of positive work - family spillover. This study showed that the positive experiences of the employees in their family lives increased their work engagement and their positive experiences in the working life. These positive experiences again had positive reflections in the family life. Based on these results, we recommend employers to give importance to practices such as providing childcare support for employees with children, care support for employees with elderly parents and relatives, paid and unpaid annual leaves for creating a familyfriendly corporate culture. Supporting the family life of employees by adapting family-friendly policies and practices might increase job performance through an increase level of work engagement.

This study has some limitations as well as possible contributions to theoretical and practical field. First, research findings are based on the perception of the participants. It is argued that the answers of the participants do not fully reflect the real situation due to the social desirability problem in data collection with the selfreporting method. In order to reduce the impact of this problem on the research findings, questions about the identity of the participants were not asked in the questionnaire forms and it was guaranteed that the answers would be confidential. Second, all the variables of this research are collected in a single time point. In this case, the measurement error, which is called common variance error and causes autocorrelation, might occur (Podsakoff et al., 2003). In order to detect common variance error, necessary tests were performed (disciriminant validity) and it was determined that there was no autocorrelation between variables. Another limitation of this study is the research sample. Research was carried out in a single-center hospital. In terms of the generalizability of the research results, the research model should be tested in different sectors and samples. Finally, not all variables that could affect research variables were added to the research model. It is suggested that other variables included in the model developed by Greenhouse 
and Powell (2006) (e.g. sources produced in the role, regulatory variables) are added to this research model and tested.

\section{Acknowledgements}

This study has been developed by training and activities organized within the scope of TUBITAK 4005 project numbered 118B056.

\section{Statement of Conflict of Interest}

Authors have declared no conflict of interest.

\section{ISŞ - AİLE YAYILIMI VE ÇALIŞMAYA TUTKUNLUĞUN ARACI ROLÜ}

\section{GİIŞ}

Bireyler gerek iş hayatlarında gerekse iş dışı hayatlarında çeşitli rollere sahiptir (ebeveyn rolü, eş rolü, çocuk rolü, yönetici rolü vb.) ve bu rollerin birey ve bireyin yaşamı üzerinde olumlu ya da olumsuz bazı etkileri mevcuttur. Bireylerin sahip olduğu bu rollerin (iş ve aile yaşam alanlarından kaynaklanan) bireyler üzerindeki etkisini açıklayan iki görüş bulunmaktadır (Rothbard, 2001). Bunlardan birincisi, rollerin birbirini olumsuz olarak etkilediği kaynak tükenmesi ve rol çatışması ile ilgili olan tüketme görüşüdür (Rothbard, 2001). İş-aile çatışması üzerine yapılan çalışmalar genellikle bu görüşü benimsemektedir. Literatürde, iş-aile çatışması, negatif iş-aile yayılması olarak görülmektedir (Jin, Ford ve Chen, 2013; Kinnunen, Geurtsve Mauno, 2004; Roehling, Jarvis ve Swope, 2005; Wayne, Lemmon, Hoobler, Cheung ve Wilson, 2017). İkinci görüş ise bir rolün diğer role katkı sağlayacağını öne süren zenginleştirme görüşüdür (Rothbard, 2001). Zenginleştirme görüşüne göre birçok role bağlı olmak bireyi tüketmekten ziyade bireye çeşitli faydalar sağlamaktadır (Rothbard, 2001). İş-aile etkileşiminde bu görüşü pozitif taşma teorisi desteklemektedir (Andreassen, Hetland, \& Pallesen, 2013; Haar \& Bardoel, 2008; Kinnunen, Feldt, Geurts, \& Pulkkinen, 2006; Stevanovic \& Rupert, 2009; Stevens, Minnotte, Mannon, \& Kiger, 2007).

İş-aile yayılımı, negatif iş-aile yayılımı ve pozitif iş-aile yayılımı olarak iki grupta incelenmektedir (Geurts et al., 2003; Grzywacz, 2000). Negatif iş-aile yayılımı, "iş ve aile alanlarından gelen rol taleplerinin bazı açılardan birbiri ile uyumlu olmaması sonucu oluşan roller arası çatışma biçimi” olarak tanımlanmaktadır (Greenhaus \& Beutell, 1985, s. 77). Negatif iş - aile yayılımı işin aileye negatif yayılımı ve ailenin işe negatif yayılımı olmak üzere çift yönlüdür (Carlson, Kacmar, \& Williams, 2000).

Pozitif iş-aile yayılımı, iş-aile yardımlaşması ve iş-aile zenginleştirmesi kavramları 
birbirlerinin yerine kullanılabilmektedir (Greenhaus, \& Powell, 2006). Pozitif işaile yayılımı; bireyin bir yaşam alanındaki görevlerine tutkun olmasının, diğer yaşam alanındaki görevlerini daha iyi yerine getirmesini destekleyecek kazanımlar sağlamasıdır (Wayne et al., 2006). Pozitif iş-aile yayılımı da negatif iş-aile yayılımı gibi iki yönlüdür ve her ikisinin de öncülleri ve sonuçları farklıdır (Grzywacz \& Butler, 2005). İşin aileye olan yardımı anlamına gelen pozitif işten-aileye yayılım; iş yaşamının sağladığı yetenek, davranış ve pozitif duygusal durumun aile yaşamını olumlu olarak etkilemesidir. Ailenin işe olan yardımı anlamına gelen pozitif aileden-işe yayılım ise aile yaşamının sağlamış olduğu duygusal durum, destek ve başarma hissinin iş hayatını olumlu etkilemesidir (Wayne, Musisca, \& Fleeson, 2004).

$\mathrm{Bu}$ araştırmanın amacı, Greenhause ve Powel (2006) tarafından geliştirilen modele dayanarak, pozitif ve negatif aile-iş yayılımının çalışmaya tutkunluk aracılığı ile pozitif ve negatif iş-aile yayılımı üzerindeki etkisini belirlemektir. Greenhause ve Powel (2006) geliştirdikleri modellerinde sadece pozitif iş-aile yayılımını incelemişlerdir. Bu çalışmada, pozitif ve negatif iş-aile yayılımı birlikte incelenecektir. Araştırmanın hipotezleri aşağıdaki gibidir:

H1: Pozitif aileden-işe yayılımının çalışmaya tutkunluk aracılığı ile pozitif iştenaileye yayılım üzerinde etkisi vardır.

H2: Negatif aileden-işe yayılımın çalışmaya tutkunluk aracılığ aileye yayılım üzerinde etkisi vardır.

\section{ARAŞTIRMA YÖNTEMİ VE BULGULAR}

Araştırmanın evrenini bir devlet hastanesinde çalışan 490 sağlık çalışanı oluşturmaktadır. Araştırmaya katılmayı kabul eden ve tüm sorulara cevap veren 228 personeli çalışmanın örneklemini oluşturmuştur.

Veriler anket yöntemi kullanılarak toplanmıştır. Tüm ölçekler 5’li Likert tipi ölçeklerdir (1 = Hiçbir zaman, 5 = Her Zaman). İş-aile yayılımını ölçmek için Grzywacz ve Marks (2000) tarafından geliştirilen ölçek kullanılmıştır. Bu ölçeğin dört alt boyutu vardır. Bunlar, negatif işten-aileye yayılım, negatif aileden-işe yayılım, pozitif aileden-işe yayılım ve pozitif işten-aileye yayılımdır. Ölçek Polatçı (2014) tarafından Türkçe’ye uyarlanmıştır. Polatçı’nın (2014) çalışmasında ölçeğin iç tutarlılı̆̆ tüm alt boyutlar için 0,70’in üzerindedir.

Çalışmaya tutkunluk boyutunu ölçmek için Utrech Çalışmaya Tutkunluk Ölçeği (UWES-3) kullanılmıştır. Schaufeli ve arkadaşları (2017) bu ölçeğin beş ülkede geçerliliğini test etmiş ve ölçeğin Cronbach Alfa güvenilirlik katsayısının beş ülkede de 0,70'in üzerinde olduğunu bildirmişlerdir. Şahin ve Çankır (2018) bu ölçeğin Türkiye'de geçerliliğini ve güvenilirliğini test etmiş ve ölçeğin Cronbach Alfa güvenirlik katsayısının 0.88 olduğunu raporlamışlardır. 
Verilerin analizinde SPSS 22 ve LISREL 8.80 programları kullanıldı. Değişkenler arasındaki korelasyonlar incelendiğinde ise negatif iş-aile yayılımı ile negatif aile-iş yayılımı arasındaki korelasyon $(\mathrm{r}=0,582, \mathrm{p}<0,01)$ ile pozitif iş-aile yayılımı ile pozitif aile-iş yayılımı arasındaki korelasyon $(\mathrm{r}=0,392, \mathrm{p}<0,01)$ anlamlıdır. Aracı değişken olan çalışmaya tutkunluk değişkeninin bütün değişkenlerle olan korelasyonları da anlamlı bulunmuştur $(\mathrm{p}<0,01)$. Ayrıca değişkenler ait Cronbach's Alpha katsayıları da 0,70’in üzerindedir.

Araştırma modelinin test edilmesi sonucunda $\mathrm{H} 1$ hipotezinin desteklendiği belirlenmiştir. Ancak araştırmanın ikinci hipotezi olan H2 hipotezi verielerle desteklenmemiştir. Araştırmanın bulgularına göre, pozitif aileden-işe yayılım tek başına pozitif işten-aileye yayılımın \%37'sini açıklamaktadır ve standardize edilmiş beta katsayısı 0,61'dir. Pozitif aileden-işe yayılım çalışmaya tutkunluk aracılığıyla ise pozitif işten-aileye yayılımın \%44'ünü açıklamaktadır ve standardize edilmiş beta katsayısı 0,61'den 0,42'ye düşmektedir. Bu bulgular çalışmaya tutkunluğun pozitif aileden-işe yayılımın pozitif işten-aileye yayılım üzerindeki etkisinde kısmi aracı rolü olduğunu göstermektedir.

\section{TARTIŞMA ve SONUÇ}

$\mathrm{Bu}$ çalışma pozitif ve negatif aileden-işe yayılımın çalışmaya tutkunluk aracılığ ile pozitif ve negatif işten-aileye yayılımın üzerindeki etkisini belirlemek amacıyla gerçekleştirilmiştir. Sağlık çalışanlarından oluşan örneklem üzerinde araştırma modeli test edilmiştir. Araştırma bulgularına göre bazı önemli sonuçlar elde edilmiştir.

Birincisi, pozitif aileden-işe yayılımın çalışmaya tutkunluğu arttırdığı ve çalışmaya tutkunluğun kısmi aracılığ yönde etkilediği bulunmuştur. Öncelikle pozitif aileden-işe yayılımın çalışmaya tutkunluk üzerindeki etkisi istatistiksel olarak anlamlı bulunmuştur. Pozitif aileden-işe yayılımın çalışmaya tutkunluk ile ilişkisini inceleyen bir çalışmaya rastlanılmamıştır. Literatürde pozitif iş-aile yayılımının çalışmaya tutkunluğun sonuçları olarak incelendiği çalışmalar mevcuttur (Culbertson, Mills, \& Fullagar, 2012; Siu et al., 2010). Siu ve arkadaşları (2010), çalışmaya tutkunluğun pozitif işten-aileye ve pozitif aileden-işe yayılımı olumlu yönde etkilediğini raporlamıştır. Culbertson, Mills, \& Fullagar, (2012) ise çalışmaya tutkunluğun pozitif ailedenişe yayılımı olumlu yönde etkilediğini raporlamıştır. Bu bulgular bu çalışmanın sonuçları ile paralellik göstermektedir. Bu çalışmada da çalışmaya tutkunluğun pozitif işten-aileye yayılımı olumlu olarak etkilediği bulunmuştur. Ayrıca bu çalışmada negatif iş-aile yayılımı ile çalışmaya tutkunluk arasında anlamlı ve ters yönlü ilişki olmasına rağmen, negatif aileden-işe yayılımın çalışmaya tutkunluk aracılığı ile negatif işten-aileye yayılım üzerindeki etkisi anlamsız bulunmuştur. $\mathrm{Bu}$ bulgunun çalışmaya tutkunluğun pozitif duygularla yakından ilişkili olması sonucunda ortaya çıkması olasıdır. 
$\mathrm{Bu}$ araştırmanın sonuçları ile pozitif iş-aile yayılımının önemine yönelik uygulama alanına ve yöneticilere önemli bulgular sağlandığı düşünülmektedir. Araştırmanın bulguları çalışanların aile yaşamlarındaki pozitif deneyimlerinin işyerinde çalışmaya tutkunluklarını artırdığını ve iş hayatındaki pozitif deneyimlerinin de aile hayatına tekrar olumlu yansımaları olduğunu göstermiştir. Bu bulgudan yola çıkarak, işverenlere çocuğu olan çalışanlara çocuk bakım desteği sağlamak, yaşlı ebeveyn ve akrabaları olan çalışanlara bakım desteği sağlamak, ücretli ve ücretsiz senelik izinler, aile dostu kurum kültürü oluşturmak gibi uygulamalara önem vermelerini önermekteyiz. İşletmelerin aile dostu politika ve uygulamaları benimseyerek çalışanların aile hayatına destek olmaları, işyerinde çalışmaya tutkunluk düzeyindeki artış aracılığı ile işletme performansını artırabilir.

\section{REFERENCES}

Adeboye, N. O., Fagoyinbo, I. S., \& Olatayo, T. O. (2014). Estimation of the Effect of Multicollinearity on the Standard Error for Regression Coefficients. IOSR Journal of Mathematics, 10(4), 16-20. Retrieved from http://www.iosrjournals.org/iosr-jm/papers/ Vol10-issue4/Version-1/D010411620.pdf

Andreassen, C. S., Hetland, J., \& Pallesen, S. (2013). Workaholism and work-family spillover in a cross-occupational sample. European Journal of Work and Organizational Psychology, 22(1), 78-87. https://doi.org/10.1080/1359432X.2011.626201

Bolino, M. C., \& Turnley, W. H. (2005). The personal costs of citizenship behavior: the relationship between individual initiative and role overload, job stress, and work-family conflict. Journal of Applied Psychology, 90(4), 740-748.

Byrne, B. M. (2001). Structural Equation Modeling With AMOS, EQS, and LISREL: Comparative Approaches to Testing for the Factorial Validity of a Measuring Instrument. International Journal of Testing. 1(1), 55-86, https://doi.org/10.1207/S15327574IJT0101_4

Carlson, D. S., Kacmar, K. M., \& Williams, L. J. (2000). Construction and Initial Validation of a Multidimensional Measure of Work-Family Conflict. Journal of Vocational Behavior, 56(2), 249-276. https://doi.org/10.1006/jvbe.1999.1713

Clark, S. C. (2000). Work/family border theory: A new theory of work/family balance. Human Relations. 53(6), 747-770, https://doi.org/10.1177/0018726700536001

Culbertson, S. S., Mills, M. J., \& Fullagar, C. J. (2012). Work engagement and work-family facilitation: Making homes happier through positive affective spillover. Human Relations, 65(9), 1155-1177. https://doi.org/10.1177/0018726712440295

Demerouti, E., A. B. Bakker, F. Nachreiner ve W. B. Schaufeli.(2001). The Job Demands Resources Model of Burnout. Journal of Applied Psychology. 86(3), 499-512.Job Demands

Frone, M. R., Russell, M., \& Cooper, M. L. (1992). Antecedents and outcomes of work-family conflict: testing a model of the work-family interface. The Journal of Applied Psychology, 77(1), 65-78. https://doi.org/10.1037/0021-9010.77.1.65

Geurts, S. A. E., Kompier, M. A. J., Roxburgh, S., \& Houtman, I. L. D. (2003). Does WorkHome Interference mediate the relationship between workload and well-being? Journal of Vocational Behavior, 63(3), 532-559. https://doi.org/10.1016/S0001-8791(02)00025-8

Giacalone, M., Panarello, D., \& Mattera, R. (2018). Multicollinearity in regression: an efficiency comparison between Lp-norm and least squares estimators. Quality and Quantity, 52(4), 1831-1859. https://doi.org/10.1007/s11135-017-0571-y

Greenhaus, J. H., \& Beutell, N. J. (1985). Sources of conflict between work and family roles. 
Academy of Management Review, 10(1), 76-88.

Greenhaus, J. H., \& Powell, G. N. (2006). When Work and Family Are Allies: A Theory of WorkFamily Enrichment. Academy of Management Review, 31(1), 72-92.

Grzywacz, J. G. (2000). Work-family spillover and health during midlife. Is managing coflict everything. American Journal of Health Promotion, 14(4), 236-243.

Grzywacz, J. G., \& Butler, A. B. (2005). The impact of job characteristics on work -to- family facilitation: Testing a theory and distinguishing a construct. Journal of Occupational Health Psychology, 10(2), 97-109. https://doi.org/10.1037/1076-8998.10.2.97

Grzywacz, J. G., \& Marks, N. F. (2000). Reconceptualizing the work-family interface: An ecological perspective on the correlates of positive and negative spillover between work and family. Journal of occupational health psychology, 5(1), 111-126.

Haar, J. M., \& Bardoel, E. A. (2008). Positive spillover from the work-family interface: A study of Australian employees. Asia Pacific Journal of Human Resources, 46(3), 275-287. https:// doi.org/10.1177/1038411108095759.

Hair, J. F., Anderson, R. E., Tatham, R. L., Black, W. C., Babin, B. J., \& Anderson, R. E. (2010). Multivariate Data Analysis Seventh Edition. In Pearson Prentice Hall. https://doi. org/10.1348/000712602761381358

Hooper, D., Coughlan, J., \& Mullen, M. R. (2008). Structural equation modelling: Guidelines for determining model fit. Electronic Journal of Business Research Methods. 6(1), 53-60, https://doi.org/10.1037/1082-989X.12.1.58

Ilies, R., Wilson, K. S., Wagner, D. T., \& Wagner, D. T. (2017). The Spillover of Daily Job Satisfaction onto Employees ' Family Lives: The Facilitating Role of Work-Family Integration. Academy of Management Journal, 52(1), 87-102.

Jin, J. F., Ford, M. T., \& Chen, C. C. (2013). Asymmetric Differences in Work-Family Spillover in North America and China: Results from Two Heterogeneous Samples. Journal of Business Ethics, 113(1), 1-14. https://doi.org/10.1007/s10551-012-1289-3

Jöreskog, K. G. (1993). Testing Structural Equation Models. In K. A. Bollen, \& J. S. Long (Eds.), Testing Structural Equation Models (pp. 294-316). Thousand Oaks, CA: Sage. https://doi. org/10.1039/b812223g

Kinnunen, U., Feldt, T., Geurts, S., \& Pulkkinen, L. (2006). Types of work-family interface: Wellbeing correlates of negative and positive spillover between work and family. Scandinavian Journal of Psychology, 47(2), 149-162. https://doi.org/10.1111/j.1467-9450.2006.00502.x

Kinnunen, U., Geurts, S., \& Mauno, S. (2004). Work -to- family conflict and its relationship with satisfaction and well-being: A one-year longitudinal study on gender differences. Work and Stress, 18(1), 1-22. https://doi.org/10.1080/02678370410001682005

Kline, R. B. (2011). Principles and Practice of Structural Equation Modelling. The GuilFord Press. https://doi.org/10.1017/CBO9781107415324.004

Kossek, E., \& Ozeki, C. (1998). Work-family conflict, policies, and the job-life satisfaction relationship: A review and directions for organizational behavior-human resources research. Journal of Applied Psychology, 83(2), 139-149. http://dx.doi.org/10.1037/00219010.83.2.139

Mansfield, E. R., Helms, B. P., Mansfield, E. R., Helms, B. P., Imax, J., \& Vlv, C. (2018). Detecting Multicollinearity, The American Statistician, 36(3a), 158-160.

Matias, M., Ferreira, T., Vieira, J., Cadima, J., Leal, T., \& Mena Matos, P. (2017). Workplace family support, parental satisfaction, and work-family conflict: Individual and crossover effects among dual-earner couples. Applied Psychology, 66(4), 628-652.

Matysiak, A., Mencarini, L., \& Vignoli, D. (2016). Work-family conflict moderates the 
relationship between childbearing and subjective well-being. European Journal of Population, 32(3), 355-379.

Netemeyer, R. G., Boles, J. S., \& Mcmurrian, R. (1996). Development and Validation of Work Family Conflict and Family - Work Conflict Scales. Journal of Applied Psychology, 81(4), 400-410. https://doi.org/10.1037/0021-9010.81.4.400

Opie, T., \& Henn, C.M. (2013). Work-family conflict and work engagement among mothers: Conscientiousness and neuroticism as moderators. SA Journal of Industrial Psychology, 39(1), 1-12.

Podsakoff, P. M., MacKenzie, S. B., Lee, J. Y., \& Podsakoff, N. P. (2003). Common Method Biases in Behavioral Research: A Critical Review of the Literature and Recommended Remedies. Journal of Applied Psychology. 88(5), 879-903. https://doi.org/10.1037/00219010.88.5.879

Polatcı, S. (2014). İş Aile Yayılımı ve Ölçme Aracının Türkçe'de Geçerlik ve Güvenilirlik Analizi. Sosyal Ekonomik Araştırmalar Dergisi, 14(27), 327-348.

Richman, A. L., Civian, J. T., Shannon, L. L., Jeffrey Hill, E., \& Brennan, R. T. (2008). The relationship of perceived flexibility, supportive work-life policies, and use of formal flexible arrangements and occasional flexibility to employee engagement and expected retention. Community, Work and Family. 11(2), 183-197. https://doi. org/10.1080/13668800802050350

Roehling, P. V., Jarvis, L. H., \& Swope, H. E. (2005). Variations in negative work-family spillover among White, Black, and Hispanic American men and women : Does ethnicity matter? Journal of Family Issues, 26(6), 840-865. https://doi.org/10.1177/0192513X05277552

Rothbard, N. P. (2001). Enriching or Depleting? The Dynamics of Engagement in Work and Family Roles. Administrative Science Quarterly, 46(4), 655-684. https://doi. org/10.2307/3094827

Schaufeli, W. B., Salanova, M., González-romá, V., \& Bakker, A. B. (2002). The measurement of engagement and burnout: A two sample confirmatory factor analytic approach. Journal of Happiness Studies. 3, 71-92. https://doi.org/10.1023/A:1015630930326

Schaufeli, W. B., Shimazu, A., Hakanen, J., Salanova, M., \& De Witte, H. (2017). An Ultra-Short Measure for Work Engagement: The UWES-3 Validation Across Five Countries. European Journal of Psychological Assessment, 1-15. https://doi.org/10.1027/1015-5759/a000430

Schaufeli, W. B., ve A. B. Bakker. (2004). Job Demands, Job Resources, and Their Relationship with Burnout and Engagement: Multi-Sample Study. Journal of Organizational Behavior. 25, 293-315.

Stevanovic, P., \& Rupert, P. A. (2009). Work-Family Spillover and Life Satisfaction Among Professional Psychologists. Professional Psychology: Research and Practice, 40(1), 62-68. https://doi.org/10.1037/a0012527

Stevens, D. P., Minnotte, K. L., Mannon, S. E., \& Kiger, G. (2007). Examining the "neglected side of the work-family interface": Antecedents of positive and negative family -to- work spillover. Journal of Family Issues, 28(2), 242-262. https://doi.org/10.1177/0192513X06294548

Şahin, S., \& Çankır, B. (2018). İş Tatmi冈ni冈ni冈n İş Performansına Etki冈siðnde Çalışmaya Tutkunluğun Aracı Rolü: Satış ve Pazarlama Sektöründe Bi冈r Araştırma. Uluslararası İktisadi ve İdari İncelemeler Dergisi, 17, 0-3. https://doi.org/10.18092/ulikidince.431440

Turgut, T. (2011). Çalışmaya Tutkunluk: İş Yükü, Esnek Çalışma Saatleri, Yönetici Desteği Ve İş-Aile Çatışması İle İlişkisi (Turkish). Ataturk University Journal of Economics \& Administrative Sciences. https://doi.org/10.16951/IIBD.74390

Voorhees, C. M., Brady, M. K., Calantone, R., \& Ramirez, E. (2016). Discriminant validity testing in marketing: an analysis, causes for concern, and proposed remedies. Journal of 
the Academy of Marketing Science. https://doi.org/10.1007/s11747-015-0455-4

Voydanoff, P. (2002). Linkages between the work-family interface and work, family, and individual outcomes: An integrative model. Journal of Family Issues. 23(1), 138-164, https://doi.org/10.1177/0192513X02023001007

Voydanoff, P. (2005). Consequences of boundary-spanning demands and resources for work -to- family conflict and perceived stress. Journal of Occupational Health Psychology. 10(4), 491-503, https://doi.org/10.1037/1076-8998.10.4.491

Wayne, J. H., Grzywacz, J. G., Carlson, D. S., \& Kacmar, K. M. (2007). Work-family facilitation: A theoretical explanation and model of primary antecedents and consequences. Human Resource Management Review, 17(1), 63-76.

Wayne, J. H., Musisca, N., \& Fleeson, W. (2004). Considering the role of personality in the work-family experience: Relationships of the big five to work-family conflict and facilitation. Journal of Vocational Behavior, 64(1), 108-130. https://doi.org/10.1016/ S0001-8791(03)00035-6

Wayne, J. H., Randel, A. E., \& Stevens, J. (2006). The role of identity and work-family support in work-family enrichment and its work-related consequences. Journal of Vocational Behavior. 69(3), 445-461, https://doi.org/10.1016/j.jvb.2006.07.002

Wayne, S. J., Lemmon, G., Hoobler, J. M., Cheung, G. W., \& Wilson, M. S. (2017). The ripple effect: A spillover model of the detrimental impact of work-family conflict on job success. Journal of Organizational Behavior, 38(6), 876-894. https://doi.org/10.1002/job.2174

Yoo, W., Mayberry, R., Bae, S., Singh, K., He, Q., \& Lillard Jr., J. (2014). A study of effects of multicollinearity in the multivariable analysis. Journal of Applied Psychology, 4(5), 9. https://doi.org/10.1016/j.biotechadv.2011.08.021.Secreted

Zedeck, S., \& Mosier, K. L. (1990). Work in the family and employing organization. American Psychologist. 45(2), 240-251, https://doi.org/10.1037/0003-066X.45.2.240

\begin{tabular}{|c|c|c|}
\hline $\begin{array}{c}\text { KATKI ORANI / } \\
\text { CONTRIBUTION RATE }\end{array}$ & $\begin{array}{c}\text { AÇIKLAMA / } \\
\text { EXPLANATION }\end{array}$ & $\begin{array}{c}\text { KATKIDA } \\
\text { BULUNANLAR / } \\
\text { CONTRIBUTORS }\end{array}$ \\
\hline $\begin{array}{c}\text { Fikir veya Kavram / Idea } \\
\text { or Notion }\end{array}$ & $\begin{array}{c}\text { Araştırma hipotezini veya fikrini } \\
\text { oluşturmak / Form the research } \\
\text { hypothesis or idea }\end{array}$ & Safiye ŞAHIN \\
\hline Tasarım / Design & $\begin{array}{c}\text { Yöntemi, ölçeği ve deseni tasarlamak / } \\
\text { Designing method, scale and pattern }\end{array}$ & Safiye ŞAHIN \\
\hline $\begin{array}{c}\text { Veri Toplama ve İşleme } \\
\text { / Data Collecting and } \\
\text { Processing }\end{array}$ & $\begin{array}{c}\text { Verileri toplamak, düzenlenmek ve } \\
\text { raporlamak / Collecting, organizing and } \\
\text { reporting data }\end{array}$ & $\begin{array}{c}\text { Safiye ŞAHIN, Vedat } \\
\text { AÇAR }\end{array}$ \\
\hline $\begin{array}{c}\text { Tartışma ve Yorum } \\
\text { / Discussion and } \\
\text { Interpretation }\end{array}$ & $\begin{array}{c}\text { Bulguların değerlendirilmesinde ve } \\
\text { sonuçlandırılmasinda sorumluluk almak } \\
\text { / Taking responsibility in evaluating and } \\
\text { finalizing the findings }\end{array}$ & $\begin{array}{c}\text { Safiye ŞAHIN, Vedat } \\
\text { AÇAR }\end{array}$ \\
\hline $\begin{array}{c}\text { Literatür Taramas1 / } \\
\text { Literature Review }\end{array}$ & $\begin{array}{c}\text { Çalışma için gerekli literatürü taramak } \\
\text { / Review the literature required for the } \\
\text { study }\end{array}$ & $\begin{array}{c}\text { Safiye ŞAHIN, Vedat } \\
\text { AÇAR }\end{array}$ \\
\hline
\end{tabular}

